Received: February 2012

Accepted: June 2012

ISSN $2006-6996$

\title{
STUDIES ON GROWTH, ORGANS WEIGHT AND HAEMATOLOGICAL PARAMETERS OF BROILER CHICKEN FED GRADED LEVEL OF SUN DRIED CASSAVA ROOT MEAL
}

\author{
Hassan ${ }^{1}$, A. M., Tamburawa ${ }^{1}$, M. S., Alponsus ${ }^{2}$, C. and Yusuf, ${ }^{1}$ J. $\mathrm{H}$. \\ ${ }^{1}$ Department of Animal Science, Faculty of Agriculture and Agricultural Technology, Kano University of Science \\ and Technology, Wudil. \\ ${ }^{2}$ Department of Animal Science, Collage of Agriculture, A.B.U., Kabba, Kogi State. \\ *Correspondence author: alhassanhassan@hotmail.com
}

\begin{abstract}
Ninety (90) day old broiler chicks were used to investigate the response of broilers fed sun-dried cassava root meal (CRM). Five diets at starter and finisher phases in which CRM replaced maize at $0,25,50,75$ and 100\% and designated T1, T2, T3, T4 and T5 respectively. Diets were allocated to day old broiler chicks in a completely randomized design (CRD). Birds were raised on dip-litter system and the experiment lasted for eight (8) weeks. Feed intake was taken daily, while body weights were recorded weekly. On days 22 and 44 two millilitres $(2 \mathrm{ml})$ of blood were collected using sterile syringe and needle from the wing vein into vacutainer tubes containing $2 \mathrm{mg}$ ethylene diamine tetra acetic acid (EDTA) as anticoagulant from two birds in each replicate. At eight weeks of age, two birds per replicate were randomly selected and used for carcass analysis. At the starter phase, final weight, daily weight gain and feed intake were significantly $(P<0.05)$ higher in $T 1$ and T2 compared to other treatments. Feed conversion efficiency tend to increase as the inclusion level of CRM increased at $(P<0.05)$. No significant difference $(P>0.05)$ was observed among the treatments for haematological parameters (PCV, Hb, MCHC and Total Protein). Highest mortality at starter and finisher phases were recorded in T4 and T5. Generally, there was decrease in feed intake as the inclusion level of CRM increased. Inclusion of CRM at finisher phase significantly affects the weight of some internal organs in T2, T3 and T4 $(P<0.05)$. It is concluded that cassava root meal could be used to replace maize up to $25 \%$ without any adverse effect on the performance of broiler chicken.
\end{abstract}

Key words: Cassava root meal, broiler chicken, feed intake, growth, organ weight, and haematological parameters.

\section{INTRODUCTION}

Nigeria, like most other developing countries, suffers greatly from a constant shortage and escalating cost of protein and energy feed resources for livestock (F.A.O., 2000). This situation has become highly magnified due to high competition between livestock and the ever growing human population for the same source of food, particularly energy feed such as maize, sorghum e.t.c. Whereas these feeds form the basic constituents of the rations for the monogastric animals form the major sources of human food (F.A.O., 2002). Also the existence of uncertain weather conditions in the grains producing areas of the country e.g. Kano State with frequent periods of drought and in some instance floods have become major causes of constant food deficit. Therefore, there is the need for livestock farmers to look for alternative sources of feeds which can be used to substitute or be included at certain level which are of less cost (F.A.O., 2002). Cassava (Manihot esculenta) root crops are planted mostly for its root for human consumption and as industrial raw- material e.g. starch (F.A.O., 2002). It is a widely cultivated crop in the tropics and the highest supplier of carbohydrates among staple crops (F.A.O., 1995). Annual production estimate in Nigeria was 34 million tonnes (F.A.O., 2002). Cassava products had been in use for a long time as an energy source in place of cereals grains for livestock (Eruvbetine et al., 2003). Cassava appears to be the best alternative for overcoming these chronic high feed cost in the livestock industry. Its cultivation requires less special expertise that applies to cereal production (e.g. Maize, Wheat, Sorghum, Millet etc) and with minimal input it yields about 10.83 tone /ha annually (FAO, 2002). Currently, Nigeria is the largest world producer of cassava (FAO, 2002). Broilers have the ability to grow fast and reach market weight faster than ruminants (Madubuike and Ekenyem, 2001). Achievement of this in poultry sector directly depends on the availability and supply of foodstuffs to meet the energy requirement of the animals for their optimum production. 
Maize which is the most available basal energy feedstuff is in constant demand for human and animal nutrition and for industrial processing (Esonu, 2000). The study was conducted to evaluate the effect of feeding graded level of cassava root meal flour on haematological and growth performance of broiler chicken.

\section{MATERIALS AND METODS \\ Study Area}

The study was conducted at the Teaching and Research Farm of the Department of Animal Science, Faculty of Agriculture and Agricultural Technology, Kano University of Science and Technology, Wudil. Located on Latitude $11^{0} 37^{\prime} \mathrm{N}$ and $11^{0} 56^{\prime} \mathrm{N}$, longitude $8^{0} 45^{\prime} \mathrm{E}$ and $8^{0} 57^{\prime} \mathrm{E}$. The average annual rainfall and temperature are $850 \mathrm{~mm}$ and $26^{\circ} \mathrm{C}$ respectively (Olofin et al., 2008).

\section{Processing of Cassava Root Meal (C.R.M.)}

The fresh cassava roots were cleaned of soil and other particles, peeled and then cut into smaller pieces. The chips were sun-dried on concrete floor for 7 days under shade after which they were milled into particulate powdered mash and stored in polythene bag prior to use as described by Aerin, 2006.

\section{Experimental Design}

Ninety (90) day old Marshal broiler chicks were used for the study. They were fed the control starter diet for seven days to stabilize. After one week, the chicks were weighed, and randomly divided into five (5) treatments of eighteen (18) chicks per treatment. Each treatment was replicated 3 times, with six (6) chicks per replicate and they were randomly allocated to the experimental diets. Routine vaccination and anticoccidial prophylaxis were given to the birds. Five experimental diets ( $\mathrm{T} 1, \mathrm{~T} 2, \mathrm{~T} 3, \mathrm{~T} 4$, and $\mathrm{T} 5)$ were formulated for each of the two phases (starter and finisher) with CRM incorporated at 0, 25, 50, 75 and 100 percent replacement of maize. T1 in both starter and finisher phases was maize - based control diet (No supplementation).Treatments 2, 3, 4 and 5 contain graded level of CRM at 25, 50, 75 and 100 percent replacement of maize respectively. The experiments lasted for 4 weeks ( 28 days) each for the starter and finisher phases. Birds were weighed on the first day of the experiment and subsequently on weekly basis. Feed and water were given ad-libitum. On day 56 two birds from each treatment were slaughtered for carcass analysis.

\section{Haematological Analysis}

Two millilitres $(2 \mathrm{ml})$ of blood were collected using sterile syringe and needle from the wing vein into vacutainer tubes containing $2 \mathrm{mg}$ ethylene diamine tetra acetic acid (EDTA) as anticoagulant from two birds in each replicate on days 24 and 44. Haematological parameters determined include: Packed Cell Volume (PCV), Haemoglobin (HB), Mean Corpuscular Haemoglobin Concentration (MCHC) and total protein as conducted by Brown and Clime (1972).

\section{Data Analysis}

Data generated from this study were analyzed using Analysis of Variance (ANOVA) (Steel and Torrie,
1980), where significant difference were observed, means were separated using Duncan Multiple Range Test (DMRT).

\section{RESULTS AND DISCUSSION}

The result of ingredients and proximate composition of the experimental diets is presented in Tables 1 and 2 for both starter and finisher phases. It shows that treatments 1 and 2 had the highest crude protein for both starter and finisher diets. Whereas dry matter, nitrogen free extract and ether extract were similar for all the treatments in the two diets. Feed intake significantly decreased $(p<0.05)$ numerically as the inclusion level of CRM increased at both starter and finisher phases (Table 3). This agrees with the findings of Ukachukwu, (2005) who reported a significant difference in daily feed intake of birds when CRM was included at 0, 20, 40,60, 80 and $100 \%$. Also Montilla (1977) reported similar result when cassava was substituted at $25,50,75$ and $100 \%$ inclusion level. A significant difference $(p<0.05)$ were observed in average daily weight gain, and feed conversion efficiency of birds at starter and finisher phases (Table 3 ), with the lowest value for birds on 75 and $100 \%$ CRM supplementation. Even though, there was no significant difference $(p>0.05)$ in final body weight and mortality of birds at both starter and finisher phases, mortality numerically increased with increase level of CRM. This may be attributed to poor diets utilization caused by high fibre content and possibly high load of hydrogen cyanide (HCN) in 75 and $100 \%$ inclusion level. This agreed with earlier report of Ukachukwu, (2005) and Akinfala (2000), who recommended inclusion level of up to $25 \%$ CRM in poultry rations. Other workers (Vogt and Penner, 1963, Yoshida et al., 1966) reported growth depression when CRM was added to poultry rations. Feeding of CRM had significant effect $(p<0.05)$ on weight gain. Birds on $0 \%$ inclusion level had the highest weight gain which was at par with birds on $25 \%$ inclusion level and higher than the rest of the treatments.

This support the finding of Montilla (1977) who reported a significant difference in daily weight gain and feed conversion efficiency when CRM was added to the diet of broilers at graded level. Results indicated no significant difference at both starter and finisher phases for blood parameters (Table 4). This agreed with the work of Allison (1955) where the value of $\mathrm{Hb}, \mathrm{PCV}$ and total protein for all the dietary treatments at starter and finisher phases fall within the normal range without any detrimental effect on haematological parameters of the birds. 
Bajopas Volume 5 Number 1 June, 2012

Table 1: Feed Composition of Broiler Starter and Finisher Diets (0-8 weeks)

\begin{tabular}{|c|c|c|c|c|c|c|c|c|c|c|}
\hline \multicolumn{11}{|c|}{ Treatments (\%) } \\
\hline \multirow[b]{2}{*}{ Ingredients } & \multicolumn{2}{|c|}{0} & \multicolumn{2}{|c|}{25} & \multicolumn{2}{|c|}{50} & \multicolumn{2}{|c|}{75} & \multicolumn{2}{|c|}{100} \\
\hline & Starter & Finisher & Starter & Finisher & Starter & Finisher & Starter & Finisher & Starter & Finisher \\
\hline Maize & 56.35 & 62.85 & 41.15 & 46.85 & 27.2 & 30.5 & 13.00 & 13.2 & 00 & 00 \\
\hline CRM & 00 & 00 & 14.2 & 15.0 & 27.2 & 30.5 & 41.35 & 44.15 & 54.35 & 57.85 \\
\hline GNC & 22.0 & 17.50 & 22.5 & 18.0 & 23.0 & 18.35 & 23.00 & 19.0 & 23.0 & 18.50 \\
\hline Fish Meal & 11.0 & 9.00 & 11.5 & 9.5 & 12.0 & 10.0 & 12.00 & 13.0 & 12.0 & 13.00 \\
\hline Bone Meal & 2.50 & 2.50 & 2.50 & 2.50 & 2.50 & 2.50 & 2.50 & 2.50 & 2.50 & 2.50 \\
\hline Wheat Offal & 6.50 & 6.50 & 6.50 & 6.50 & 6.50 & 6.50 & 6.50 & 6.50 & 6.50 & 6.50 \\
\hline Salt & 0.25 & 0.25 & 0.25 & 0.25 & 0.25 & 0.25 & 0.25 & 0.25 & 0.25 & 0.25 \\
\hline Methionine & 1.00 & 1.00 & 1.0 & 1.0 & 1.00 & 1.00 & 1.00 & 1.00 & 1.00 & 1.00 \\
\hline Lysine & 0.15 & 0.15 & 0.15 & 0.15 & 0.15 & 0.15 & 0.15 & 0.15 & 0.15 & 0.15 \\
\hline Premix & 0.25 & 0.25 & 0.25 & 0.25 & 0.25 & 0.25 & 0.25 & 0.25 & 0.25 & 0.25 \\
\hline Total & $100 \mathrm{Kg}$ & $100 \mathrm{Kg}$ & $100 \mathrm{Kg}$ & $100 \mathrm{Kg}$ & $100 \mathrm{Kg}$ & $100 \mathrm{Kg}$ & $100 \mathrm{Kg}$ & $100 \mathrm{Kg}$ & $100 \mathrm{Kg}$ & $100 \mathrm{Kg}$ \\
\hline
\end{tabular}

Vitamin premix: Vit. A 30789 IU, Vit. D 36 IU, Vit. E 115 IU, Vit. K 77 mg, Thiamine 39 mg, Pyridoxine 39 mg, Riboflavin 115 mg, calcium panthothenate 173 mg, Nicotinic acid 346 mg, VitB 120.31 mg, Folic acid 19 mg, Manganese 3 g, Zinc 2 g, Iron 1 g, Copper 115 g, Iodine 38 mg, Cobalt 8 mg, Selenium 4 mg, Antioxidant 4 g, Chloride 8 g.

Table 2: Proximate Composition of Broiler Starter and Finisher Diets

\begin{tabular}{|c|c|c|c|c|c|c|c|c|c|c|}
\hline \multicolumn{11}{|c|}{ Treatments (\%) } \\
\hline \multirow[t]{2}{*}{ Parameter (\%) } & \multicolumn{2}{|c|}{0} & \multicolumn{2}{|r|}{25} & \multicolumn{2}{|c|}{50} & \multicolumn{2}{|c|}{75} & \multicolumn{2}{|c|}{100} \\
\hline & Starter & Finisher & Starter & Finisher & Starter & Finisher & Starter & Finisher & Starter & Finisher \\
\hline DM & 93.27 & 93.72 & 93.75 & 93.95 & 92.95 & 94.15 & 93.86 & 93.86 & 93.36 & 93.36 \\
\hline $\mathrm{CP}$ & 22.63 & 20.00 & 22.38 & 19.63 & 21.97 & 19.38 & 22.12 & 19.12 & 21.25 & 19.25 \\
\hline $\mathrm{CF}$ & 6.31 & 6.38 & 7.16 & 7.65 & 7.75 & 8.75 & 8.01 & 8.651 & 5.66 & 6.66 \\
\hline $\mathrm{EE}$ & 5.67 & 5.57 & 5.29 & 5.19 & 4.99 & 4.79 & 5.02 & 5.22 & 6.00 & 6.00 \\
\hline ASH & 9.32 & 9.42 & 13.97 & 14.12 & 14.38 & 14.38 & 15.13 & 15.19 & 12.75 & 12.85 \\
\hline NFE & 56.07 & 58.63 & 51.20 & 53.41 & 50.91 & 52.70 & 49.72 & 51.82 & 54.34 & 55.24 \\
\hline
\end{tabular}

$\mathrm{DM}=$ Dry matter, $\mathrm{CP}=$ Crude protein, $\mathrm{CF}=$ Crude fibre, $\mathrm{EE}=$ Ether extract, $\mathrm{ASH}=\mathrm{Ash}, \mathrm{NFE}=$ Nitrogen free extract 
Table 3: Performance of Broiler Chicks Fed Graded Level of Cassava Root Meal at Starter and Finisher Phases

\begin{tabular}{|c|c|c|c|c|c|c|c|c|c|c|c|c|}
\hline \multirow{3}{*}{ Parameter } & \multicolumn{10}{|c|}{ Treatments (\%) } & \multirow{3}{*}{$\begin{array}{l}\text { SEM } \\
\text { Starter }\end{array}$} & \multirow{3}{*}{$\begin{array}{l}\text { SEM } \\
\text { Finisher }\end{array}$} \\
\hline & \multicolumn{2}{|c|}{$\mathbf{0}$} & \multicolumn{2}{|c|}{25} & \multicolumn{2}{|c|}{50} & \multicolumn{2}{|c|}{75} & \multicolumn{2}{|c|}{100} & & \\
\hline & Starter & Finisher & Starter & Finisher & Starter & Finisher & Starter & Finisher & Starter & Finisher & & \\
\hline $\begin{array}{l}\text { Initial Body } \\
\text { Weight (g) }\end{array}$ & 100.00 & 100.00 & 111.10 & 111.10 & 104.00 & 104.00 & 111.17 & 111.17 & 100.43 & 100.43 & 6.10 & 6.10 \\
\hline $\begin{array}{l}\text { Final Body } \\
\text { Weight (g) }\end{array}$ & $1024.27^{\mathrm{a}}$ & 1936.67 & $987.83^{\mathrm{a}}$ & 2088.3 & $614.47^{b}$ & 1560.63 & $705.58^{a b}$ & 1265.0 & $493.68^{b}$ & 1315.00 & 103.90 & 162.99 \\
\hline $\begin{array}{l}\text { Average Daily } \\
\text { Weight Gain } \\
\text { (g) }\end{array}$ & $33.01^{\mathrm{a}}$ & $67.28^{\mathrm{a}}$ & $31.31^{\mathrm{a}}$ & $33.76^{\mathrm{b}}$ & $22.02^{b}$ & $31.88^{b}$ & $21.23^{b}$ & $30.28^{b}$ & $14.62^{b}$ & $29.33^{b}$ & 3.41 & 6.52 \\
\hline $\begin{array}{l}\text { Feed Intake } \\
\text { (g) }\end{array}$ & $91.29^{a}$ & $184.98^{\mathrm{a}}$ & $82.69^{b}$ & $182.74^{a}$ & $64.26^{c}$ & $56.07^{b}$ & $54.15^{d}$ & $52.97^{c}$ & $43.34^{e}$ & $44.58^{d}$ & 8.84 & 32.49 \\
\hline $\begin{array}{l}\text { Feed } \\
\text { Conversion } \\
\text { Efficiency }\end{array}$ & $2.77^{\mathrm{a}}$ & $2.75^{a}$ & $2.64^{a}$ & $5.41^{\mathrm{a}}$ & $2.92^{b}$ & $1.76^{\mathrm{b}}$ & $2.96^{\mathrm{b}}$ & $1.75^{c}$ & $2.96^{\mathrm{b}}$ & $1.52^{d}$ & 0.08 & 1.45 \\
\hline Mortality (\%) & 0 & 0 & 0 & 0 & 11.11 & 11.11 & 22.22 & 27.77 & 22.22 & 33.33 & 8.50 & 15.50 \\
\hline
\end{tabular}

abcd Means within the same rows with different superscript are significantly different $(p<0.05)$

SEM: Standard Error of Means

Table 4: Effect of Cassava Root Meal on Haematological Parameters of Broilers at Starter and Finisher Phases

\begin{tabular}{|c|c|c|c|c|c|c|c|c|c|c|c|c|c|}
\hline \multirow{3}{*}{ Parameters } & \multicolumn{12}{|c|}{ Treatments (\%) } & \\
\hline & \multicolumn{2}{|c|}{$\mathbf{0}$} & \multicolumn{2}{|c|}{25} & \multicolumn{2}{|c|}{50} & \multicolumn{2}{|c|}{75} & \multicolumn{2}{|c|}{100} & \multirow{2}{*}{$\begin{array}{l}\text { SEM } \\
\text { Starter }\end{array}$} & \multirow{2}{*}{$\begin{array}{l}\text { SEM } \\
\text { Finisher }\end{array}$} & \\
\hline & Starter & Finisher & Starter & Finisher & Starter & Finisher & Starter & Finisher & Starter & Finisher & & & \\
\hline $\begin{array}{l}\text { Haemoglobin } \\
(\mathrm{g} / \mathrm{dl})\end{array}$ & 8.8 & 8.3 & 9.2 & 9.3 & 8.8 & 7.9 & 9.3 & 8.5 & 8.1 & 8.6 & 0.21 & 0.29 & \\
\hline $\begin{array}{l}\text { Packed Cell } \\
\text { Volume (\%) }\end{array}$ & 30.3 & 25.2 & 27.3 & 28 & 27.7 & 24.1 & 30.2 & 28.8 & 26.5 & 25.8 & 0.78 & 0.88 & \\
\hline $\begin{array}{l}\text { Mean } \\
\text { Corpuscular } \\
\text { Haemoglobin } \\
(\mathrm{g} / \mathrm{dl})\end{array}$ & 29.2 & 33.3 & 33.8 & 33.2 & 31.9 & 32.5 & 30.8 & 33.0 & 30.7 & 33.3 & 0.76 & 0.15 & SEM: Standard Error of \\
\hline $\begin{array}{l}\text { Total Protein } \\
(\mathrm{g} / \mathrm{dl})\end{array}$ & 5.4 & 5.5 & 5.8 & 5.7 & 5.9 & 5.9 & 5.8 & 6.2 & 5.3 & 5.6 & 0.13 & 0.13 & Means \\
\hline
\end{tabular}




\section{Conclusion and Recommendation}

The results obtained from this study indicated that sun-dried cassava root meal could be used to substitute maize for up to $25 \%$ in both starter and finisher phases with out deleterious effect on

\section{REFERENCES}

Allison, J. B. (1955): Biological Evaluation of Proteins Physiol. Rev., 35: 664-669.

Akinfala, E. O. (2000): Chemical and Biological Evaluation of whole Cassava Plant based Diets in Life Cycle Feeding of Pigs in South Western Nigeria Ph.D Thesis, University of Ibadan, Nigeria. (Unpublished).

Aerin, P. (2006): Mobilizing Science and Technology for Development: The case of cassava Biotechnology Network, Agbioforum. 9 (1): 1-14.

Brown, J. A. and T.R. Clime., (1972): Nutrition and haematological value S. J. Anim. Science, 35: $211-218$.

Esonu, B. O. (2000): Animal Nutrition and Feeding: $A$ Functional Approach. Memory Press, Owerri, Nigeria. Pp. 198 - 204.

Eruvbetine, D., Tajudeen, I.D., Adeosun, A. T., and Olojede, A. A. (2003): Cassava (M. esculanta) Leaf and Tuber Concentrate in Diets for Broiler Chickens. Biores. Tech., 86:277-281.

F.A.O. (1995): Commodity Review and Outlook, 1994 - 1995. Economics and Solid Development Series. Food and Agricultural Organisation. Rome, Italy.

F.A.O. (2000): FAO Production Year Book. Volume 56. Food and Agricultural Organisation of the United Nation. Rome, Italy. haematological and growth performance parameters of broiler chicken. Therefore, $25 \%$ substitution level of CRM could be used to replace maize in the diet of broilers.

F.A.O. (2002): FAO Production Year Book Volume 58. Food and Agricultural Organisation of the United Nation. Rome, Italy.

Madubuike, F.N. and Ekenyem B.U. (2001): Non Ruminant Livestock Production in the Tropics. Gust Chuks Graphic Centre, Owerri, Nigeria. Pp. $120-145$

Montilla, J. (1977): Cassava in the nutrition of Broiler as Animal feed: proceeding of a workshop held at the University of Guelph, $18^{\text {th }}-20^{\text {th }}$ April 1977. pp.43-50.

Olofin, E. A., Nabegu, A. B. and Dambazau, A. M. (2008): Wudil within Kano Region: A Geographical Synthesis, $1^{\text {st }}$ edition, Adamu Joji publishers. Department of Geography, KUST, Wudil.

Steel, R. G. D. and Torrie, J. H. (1980): Principles and Procedures of Statistics, Mc Graw Hill Book, Co., New York USA.

Ukachukwu, S. N. (2005): Studies on the Nutritive Value of Composite Cassava Pellets For Poultry: Chemical Composition and Metabolizable Energy. Livestock Research for Rural Development 17: 125.

Vogt, H. and Penner, W. (1963): Inclusion of Tapioca Meal in Food for Chickens Nutrition. Abstracts Reviews 34:886.

Yoshida, M., Mochu, H., Kosaka, K. and Morimoto, H. (1966): Nutritive value of various energy sources for Poultry Feed. Estimation of available energy of Cassava meal. Japan Poultry Science 3:29-34. 